\title{
The impact of climate on radial growth and nut production of Persian walnut (Juglans regia L.) in Southern Kyrgyzstan
}

\section{Journal Article}

Author(s):

Winter, Maria-Barbara; Wolff, Barbara; Gottschling, Hagen; Cherubini, Paolo

Publication date:

2009-11

Permanent link:

https://doi.org/10.3929/ethz-b-000084048

Rights / license:

In Copyright - Non-Commercial Use Permitted

Originally published in:

European Journal of Forest Research 128(6), https://doi.org/10.1007/s10342-009-0295-1 


\title{
The impact of climate on radial growth and nut production of Persian walnut (Juglans regia L.) in Southern Kyrgyzstan
}

\author{
Maria-Barbara Winter · Barbara Wolff · \\ Hagen Gottschling $\cdot$ Paolo Cherubini
}

Received: 2 July 2008 / Revised: 2 April 2009 / Accepted: 5 June 2009 / Published online: 8 August 2009

(C) Springer-Verlag 2009

\begin{abstract}
This dendroecological study used time series of climate and radial growth and nut production of Juglans regia to investigate the relationships between these parameters. More than 200 trees growing at sites of different altitude, aspect, inclination and human impact intensity were sampled in walnut-fruit forests of the Jalal Abad region in Southern Kyrgyzstan. Tree rings were dated and ring widths measured. Wide and narrow tree rings, so called positive and negative pointer years, could be explained by climatic events. The mean annual increment differed significantly in different regions and altitudes. The highest values could be found in plantations and at higher altitudes (1,700-2,000 m a.s.1.). Analysing the relationships between nut crop yields and annual increment, we found a significantly positive correlation between nut crop of the current year $(x)$ and ring width of the previous year $(x-1)$. This relationship is influenced by climatic conditions, and may
\end{abstract}

Communicated by C. Ammer.

\section{M.-B. Winter}

University of Natural Resources and Applied Life Sciences,

Vienna, Peter-Jordan-Straße 82, 1190 Wien, Austria

B. Wolff ( $\square)$

University of Applied Sciences Eberswalde,

Alfred-Möller-Strasse 1, 16225 Eberswalde, Germany

e-mail: bwolff@fh-eberswalde.de

H. Gottschling

Botanical Institute, University Greifswald,

Grimmer Strasse 88, 17487 Greifswald, Germany

P. Cherubini $(\square)$

WSL Swiss Federal Research Institute,

Zürcherstrasse 111, 8903 Birmensdorf, Switzerland

e-mail: paolo.cherubini@wsl.ch change in the future if climatic conditions in the region will change. Our study shows that Persian walnut (Juglans regia L.) of South Kyrgyzstan can be used in dendrochronological studies, and illustrates the influence of site conditions and management practices on radial growth of this tree species.

Keywords Dendroecology $\cdot$ Fruit production ·

Tree-ring width $\cdot$ Climate response $\cdot$ Walnut-fruit forests

\section{Introduction}

The unique walnut-fruit forests in the Southwest of Kyrgyzstan represent the world's largest naturally occurring walnut forests and are characterised by a huge diversity of trees and shrubs (Hemery and Popov 1998). Along with the main tree species, i.e. Persian walnut (Juglans regia $\mathrm{L}$.), maple (Acer turkestanica Pax) and various wild fruit-bearing species like apple (Malus siversii (Ledeb.) Roem), plum (Prunus sogdiana Vass), pear (Pyrus sp.) and hawthorn (Crataegus sp.), around 180 other woody species are found (Gan 1992; Kolov 1997; Blaser et al. 1998; Sorg et al. 2003). Presently the walnut-fruit forests cover 230,700 ha, with 25,600 ha of pure walnut stands (Blaser et al. 1998), and grow at an altitude between 1,000 and $2,000 \mathrm{~m}$ a.s.l. They are a very important natural resource for local communities and have a long history of human utilisation. For several centuries these forests have been used for nut and firewood collection, cattle grazing and hay production (Schmidt 2005). However, since Kyrgyzstan became independent in 1991, these forests have been exploited in a more and more intensified manner (Blaser et al. 1998; Gottschling et al. 2005; Schmidt 2005) leading to some extent to their degradation. 
Because tree rings are an integral of all effective growth factors (Schweingruber 1983) dendrochronological studies enable the reconstruction of tree growth history with an annual resolution. Contrary to the results of Schweingruber (1989), which showed that J. regia growing in Switzerland is not useful for dendrochronological purposes, J. regia in Southern Kyrgyzstan reacts simultaneously on climatic impacts across larger areas (Friedrichs et al. 2006) and is therefore suitable for understanding past responses of tree growth to environmental conditions. However, although several studies have been done concerning the general structure of the walnut-fruit forest ecosystem (Sukacev 1949; Gan 1970, 1992; Maydell 1983) mainly before the breakup of the Soviet Union in 1991, with some more focus on management questions since the independence of Kyrgyzstan (Blaser et al. 1998; Zamoshnikov and Vienglovsky 2003; Scheuber et al. 2000) only limited knowledge about walnut tree-ring growth in Southern Kyrgyzstan is available (e.g., Friedrichs et al. 2006) and studies of the influence of climatic conditions on tree growth and nut production in these forests are still lacking.

Reproduction of fruit trees depends on endogenous cycles, known as alternate bearing (Kozlowski and Pallardy 1997), and exogenous factors, mostly climatic. Several studies have shown that climatic conditions at a certain time of the vegetation season affect flower production and flower and fruit development (e.g., Owens 1995). Up to now the influence of climatic variations on both biotic responses, tree growth and reproduction of tree species have been analysed by only a few investigators, e.g., for Norway spruce (Picea abies (L.) Karst) by Selas et al. (2002), for sub alpine fir (Abies lasiocarpa (Hook.) Nutt.) and mountain hemlock (Tsuga mertensiana (Bong.) Carr.) by Woodward et al. (1994) and for beech (Fagus sylvatica L.) by Gruber (2003). For J. regia comparable studies are missing. It is not yet sure to what extent tree reproduction processes are influencing the annual tree-ring growth and if it should be considered within studies of the relationships between tree rings and climatic effects and/or reconstructions of climate variations using tree rings as proxies.

The aim of this study is to determine the effects of climatic conditions on radial growth and annual nut production of J. regia, while testing the following hypotheses:

1. J. regia does react considerably on exogenous changes and is therefore a suited species within dendroecology.

2. J. regia is a thermophyllous species and will react with increased growth rates on high temperatures during vegetation season.

3. Due to more regular and wider spacing, and therefore reduced competition within plantations, radial growth is expected to show larger values in plantations than in un-even aged forests.

4. On the other hand, there will be a competition for internal resources between radial growth and nut production leading to reduced growth rates in consecutive years of high nut production.

\section{Materials and methods}

\section{Site description}

The walnut-fruit forests are located in the Jalal Abad region $\left(41^{\circ}-43^{\circ} \mathrm{N}, 72^{\circ}-73^{\circ} \mathrm{E}\right)$ in the Fergana mountain range, which is situated in the western part of the Tien Shan in Southern Kyrgyzstan. The study areas are located in the two geographically separated walnut-fruit forests of the lezhoses (forest services) Arslanbob (including lezhose Kyzyl Ungur) and Kara Alma (Fig. 1). In each region, plots at lower and higher altitudes, on north and south facing slopes were selected. Altogether the investigations were conducted on 26 plots covering a maximum range of site conditions and human impacts (Table 1).
Fig. 1 Location of Kyrgyzstan, the walnut-fruit forests, the study areas Arslanbob and Kara Alma and the meteorological stations (Academie Pédagogie Marseille 2009; modified)

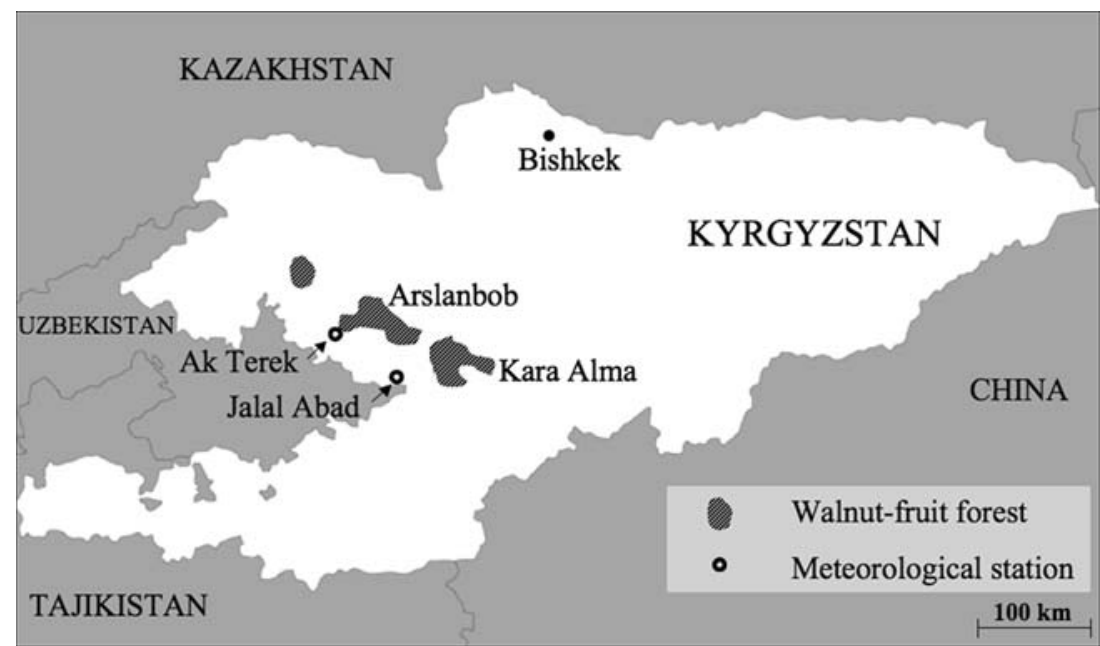


Table 1 Classification of the study plots in the walnut-fruit-forest in autumn 2005

\begin{tabular}{|c|c|c|c|c|c|c|c|c|c|c|c|c|}
\hline Region & Forest type & $\begin{array}{l}\text { Altitude level } \\
\text { (m a.s.l.) }\end{array}$ & Aspect & Plot no. & Inclination & $\begin{array}{l}\text { No. of } \\
\text { sampled } \\
\text { trees }\end{array}$ & Germination & $\begin{array}{l}\text { Wood } \\
\text { extraction }\end{array}$ & Grazing & $\begin{array}{l}\text { Human } \\
\text { impact } \\
\text { factor } \\
\text { (HIF) }\end{array}$ & $\begin{array}{l}\text { Component } \\
\text { and loading } \\
\text { without } \\
\text { rotation }\end{array}$ & $\begin{array}{l}\text { Component } \\
\text { and loading } \\
\text { with } \\
\text { Varimax } r\end{array}$ \\
\hline A & Un-even aged & $1,400-1,700$ & - & 13 & 0 & 11 & 1 & 3 & 3 & 7 & $1 / 0.80$ & $3 / 0.61$ \\
\hline A & Un-even aged & $1,400-1,700$ & - & 14 & 0 & 14 & 1 & 3 & 3 & 7 & $1 / 0.82$ & $3 / 0.69$ \\
\hline A & Un-even aged & $1,400-1,700$ & North & 10 & 6 & 9 & 1 & 2 & 2 & 5 & $1 / 0.72$ & $2 / 0.71$ \\
\hline A & Un-even aged & $1,400-1,700$ & North & 1 & 8 & 6 & 2 & 2 & 3 & 7 & $1 / 0.67$ & $4 / 0.89$ \\
\hline A & Un-even aged & $1,400-1,700$ & North & 25 & 19 & 15 & 1 & 2 & 1 & 4 & $1 / 0.87$ & - \\
\hline A & Un-even aged & $1,400-1,700$ & North & 26 & 24 & 6 & 1 & 3 & 3 & 7 & $1 / 0.77$ & $4 / 0.63$ \\
\hline A & Un-even aged & $1,400-1,700$ & North & 21 & 25 & 5 & 1 & 3 & 3 & 7 & $1 / 0.82$ & $4 / 0.72$ \\
\hline A & Un-even aged & $1,400-1,700$ & North & 17 & 30 & 4 & 1 & 2 & 3 & 6 & $1 / 0.63$ & $3 / 0.93$ \\
\hline A & Un-even aged & $1,400-1,700$ & South & 22 & 8 & 10 & 2 & 3 & 3 & 8 & $1 / 0.81$ & $3 / 0.71$ \\
\hline A & Un-even aged & $1,400-1,700$ & South & 8 & 16 & 4 & 1 & 3 & 3 & 7 & $1 / 0.88$ & - \\
\hline A & Un-even aged & $1,700-2,000$ & North & 11 & 10 & 11 & I & 2 & 2 & 5 & $1 / 0.68$ & $2 / 0.83$ \\
\hline A & Un-even aged & $1,700-2,000$ & North & 12 & 26 & 9 & 1 & 2 & 1 & 4 & $1 / 0.83$ & $2 / 0.68$ \\
\hline A & Un-even aged & $1,700-2,000$ & North & 24 & 28 & 6 & 1 & 2 & 2 & 5 & $1 / 0.81$ & - \\
\hline A & Un-even aged & $1,700-2,000$ & South & 9 & 10 & 10 & 1 & 1 & 3 & 5 & $1 / 0.69$ & $2 / 0.82$ \\
\hline $\mathrm{K}$ & Un-even aged & $1,400-1,700$ & North & 2 & 35 & 12 & 1 & 0 & 1 & 2 & $1 / 0.83$ & $1 / 0.56$ \\
\hline $\mathrm{K}$ & Un-even aged & $1,400-1,700$ & South & 16 & 30 & 11 & 1 & 2 & 2 & 5 & $1 / 0.68$ & $1 / 0.59$ \\
\hline $\mathrm{K}$ & Un-even aged & $1,700-2,000$ & North & 5 & 31 & 9 & 1 & 1 & 1 & 3 & $1 / 0.82$ & $1 / 0.63$ \\
\hline $\mathrm{K}$ & Un-even aged & $1,700-2,000$ & North & 3 & 33 & 12 & 1 & 0 & 1 & 2 & $1 / 0.80$ & - \\
\hline $\mathrm{K}$ & Un-even aged & $1,700-2,000$ & South & 15 & 16 & 13 & 1 & 0 & 2 & 3 & $1 / 0.79$ & $1 / 0.73$ \\
\hline $\mathrm{K}$ & Un-even aged & $1,700-2,000$ & South & 4 & 32 & 7 & 1 & 0 & 1 & 2 & $1 / 0.76$ & $1 / 0.70$ \\
\hline A & Plantation & $1,400-1,700$ & - & 20 & 0 & 5 & 3 & 3 & 3 & 9 & $3 / 0.52$ & $5 / 0.60$ \\
\hline A & Plantation & $1,400-1,700$ & South & 18 & 2 & 5 & 3 & 3 & 3 & 9 & $2 / 0.67$ & $5 / 0.86$ \\
\hline A & Plantation & $1,400-1,700$ & South & 23 & 2 & 4 & 3 & 3 & 3 & 9 & $2 / 0.73$ & - \\
\hline A & Plantation & $1,400-1,700$ & South & 19 & 7 & 3 & 3 & 1 & 3 & 7 & $2 / 0.66$ & - \\
\hline $\mathrm{K}$ & Plantation & $1,700-2,000$ & South & 7 & 3 & 3 & 3 & 2 & 3 & 8 & - & - \\
\hline $\mathrm{K}$ & Plantation & $1,700-2,000$ & South & 6 & 14 & 11 & 3 & 2 & 2 & 7 & $2 / 0.71$ & - \\
\hline
\end{tabular}

(A Arslanbob, K Kara Alma)

Calculation of the human-impact-factor (HIF):

Germination: natural $=1 ;$ resprouting $=2 ;$ plantation $=3 ;$ Wood extraction: low $=1 ;$ medium $=2 ;$ strong $=3 ;$ Grazing: low $=1 ;$ medium $=2$; strong $=3$

HIF = Sum (germination, wood extraction, grazing)

The climate is subtropical in the Fergana Valley, but the walnut-fruit forests on the slopes benefit from the predominantly westerly wind directions and the air masses ascending to the top of the Fergana Mountains. This leads to an annual precipitation of $700 \mathrm{~mm}$ at lower elevation $(1,000 \mathrm{~m}$ a.s.l.) and of up to $1,200 \mathrm{~mm}$ at the highest (2,000 $\mathrm{m}$ a.s.l.) (Ponomarenko and Kenzhekaraev 1992), with most precipitation in spring and autumn (Fig. 2).

During winter, the high mountain range of Tien Shan, located in the northern part of the study area, protects the forests from strong winds transporting cold air masses from Siberia. The mean temperature of January in Ak Terek (1,750 $\mathrm{m}$ a.s.1.) is $-1.7^{\circ} \mathrm{C}$ (in the period $1983-2004$ ).

All forests are used by local people, but with different intensities of cattle grazing, firewood and nut collection. The results are, among others, browsing damages of different intensities, reduced natural regeneration and a loss of biodiversity caused by a selective, but intensive collection of firewood (Gottschling et al. 2005). In order to include the degree of human influence in the forests the "human impact factor' (HIF) was calculated. The HIF is the sum of values characterising the intensity of wood extraction and cattle grazing ( $1=$ low; $2=$ medium; $3=$ strong $)$ and the kind of germination $(1=$ natural regeneration (from seeds); $2=$ resprouting (coppice); $3=$ plantation) (Table 1). The classes of utilisation intensity have been recorded by qualitative assessment in the field. Nut collection takes place in all stands comparably and is not included in the calculation of the HIF. Intercorrelation has been calculated between the different site variables (altitude, aspect, inclination and HIF). 
Fig. 2 Mean monthly precipitation $(\mathrm{mm})$ (grey columns) and temperature $\left({ }^{\circ} \mathrm{C}\right)$ (black line) at Ak Terek (1,750 m a.s.1) (19832004)

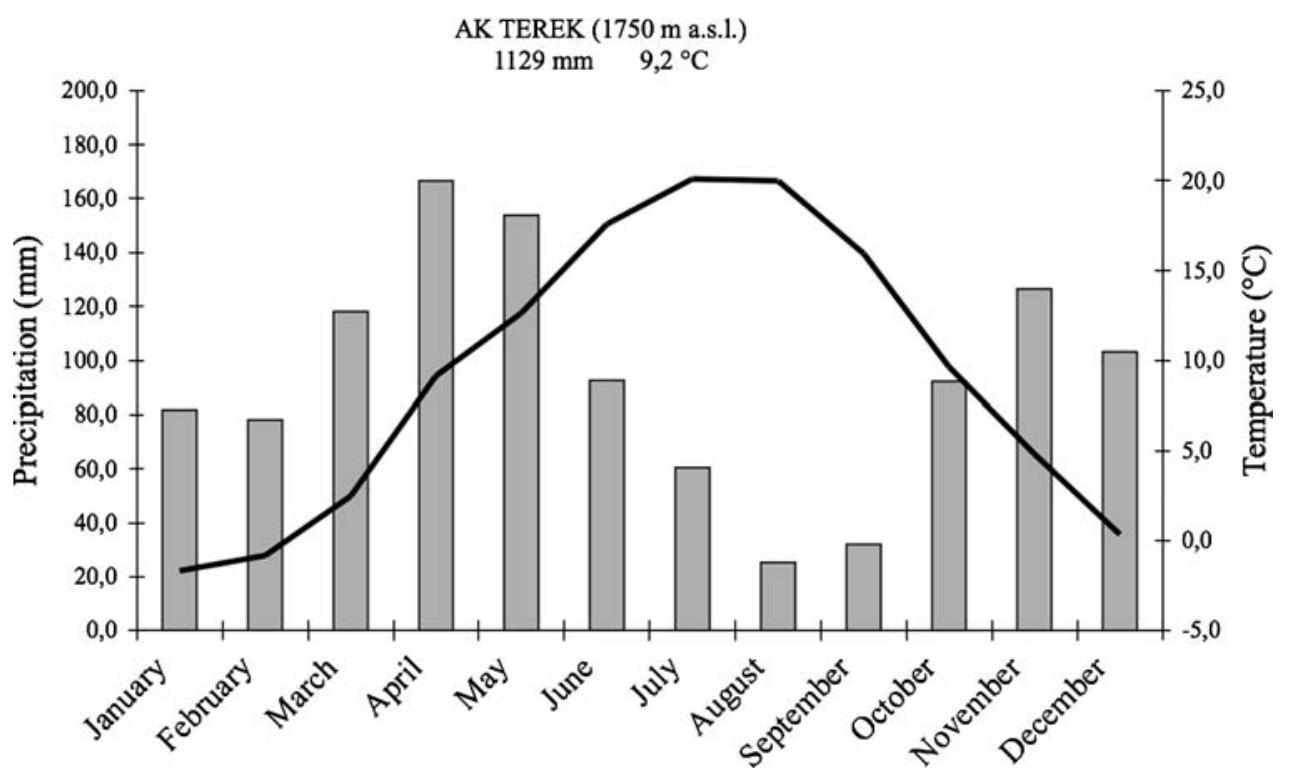

Tree-ring series

For dendrochronological purposes, 10-70 trees (dominant, co-dominant and suppressed) were sampled in each forest type (same region, altitude, origin and aspect), taking one or two increment cores (using a tree corer $0.5 \mathrm{~cm}$ in diameter) from each tree at breast height (Table 1).

All sampled trees were older than 20 years, which corresponds to the average age at which J. regia starts to reproduce. Reaction wood was excluded by avoiding sampling up- or downhill. The samples were processed following Pilcher (1990). Ring width was measured using the measuring linear table Lintab (Rinn, Heidelberg, Germany) and the software Time Series And Presentation Program (TSAP) (Rinn 1996). The raw ring widths of the single curves were plotted and the curves first checked visually and then synchronized by the "Gleichläufigkeit" and the Student's $t$ test in the TSAP program. To remove any age trend the raw crossdated series were standardised using the HUGERSHOFF equation within the Arstan software (Bräker 1981; Cook and Holmes 1986). The single curves were combined into mean tree and plot chronologies. After running the Principal Component Analysis chronologies were built, showing the mean growth of the plots loaded by one component.

According to Schweingruber et al. (1990), an abrupt growth change in annual tree growth occurs when the ring width is at least $40 \%$ smaller or $160 \%$ wider than that of the preceding 4 years. If at least $50 \%$ of the trees of one plot show an abrupt growth change in the same year, this year is known as a "pointer year". We named "regional pointer years" such years when more than $75 \%$ of the trees show a synchronous pointer year in one of the two regions Arslanbob and Kara Alma, whereas synchronous pointer years in the two regions are named "inter-regional pointer years".

\section{Nut crop series}

Annual nut crop in tons of the whole walnut forest area in South Kyrgyzstan during the period 1932-1990 and separately for each regional forest service (1979-2002) was recorded by the State Forest Service of the Kyrgyz Republic. The correlation between the yearly sums of the two series for the common period 1979-1990 is very high $(r=0.98)$ with the values of the time series for whole South Kyrgyzstan being on average $28 \%$ higher than the sum of the separated series of the State Forest Service $(\mathrm{CV}=0.24)$, due to an incomplete list of the regional forest services. For the period 1991-2002 the values of the summarized series of the State Forest Service were multiplied by 1.28 and then combined with the values of the other series to generate one series based upon both values for the period from 1932 to 2002.

\section{Climatic series}

The climatic data used consisted of monthly values of precipitation (sum) and temperature (mean) from the meteorological station at Jalal Abad (971 $\mathrm{m}$ a.s.1.) for the years 1947 to 2000, and decadal values of air temperature (maximum and minimum) and precipitation (sum) (1983-2004) from the only meteorological station located between the walnut-fruit forests at $\mathrm{Ak}$ Terek (1,750 m a.s.1.) (see Fig. 1). For the period 1983-2000 there was, despite the large difference of altitude, a high mean correlation between monthly temperature and precipitation values of the two meteorological stations $(r=0.7)$. 
Statistical analyses

Response function analyses were used to study the relationships between nut production, tree growth and climatic variables. The Precon5-program (Fritts and Shaskin 1995) running the bootstrap method (Guiot 1991) with 100 replication steps was applied for the analyses. The response functions for tree growth were calculated from May of the previous year to October of the current year, considering 3 years' prior growth for a 53-year-period (1948-2000). The response functions for nut crop considered a 41-yearperiod (1960-2000) from January of the previous year to December of the current year, taking also a 3-year lag of prior nut crop into account. Both the tree growth and the nut crop series were also compared with the occurrence of late frost during the flowering season at the end of April and the beginning of May for the period from 1983 to 2004, defining any temperature lower than $0^{\circ} \mathrm{C}$ as frost.

To group the study plots to classes of similar growth patterns, the Principal Component Analysis (PCA) (SPSS 13.0 for Windows 2004) was conducted. For this purpose the plot chronologies with the values of annual radial growth were analysed with the PCA for the period 1960-2005, first without rotating the data, later with Varimax rotation. Components fulfilling the Kaiser criterion (Eigenvalues $>1$ ) and showing values larger than 0.5 for the loading of the variables (plot chronologies) in the component matrix were used for further calculations. The plots loaded by the same component were grouped and mean growth chronologies were built and described in $x y$-Plots.

To investigate the relationships between annual nut crop and radial increment the series were checked on their correlation using SPSS. The correlation was first calculated between the nut crop of South Kyrgyzstan and the growth chronology (mean growth of all sampled trees). Later the annual nut crop was compared in detail with the growth chronologies of the different component loadings. In all analyses the correlation was calculated between the nut crop $(x)$ and the growth of the same year $(x)$, the growth of the previous year $(x-1)$ and the growth of the three following years $(x+\ldots)$. In order to exclude the climatic influence in the series of nut crop and growth, the residuals of the climatic investigations in Precon were used for the comparison. The level of significance $(P)$ for all statistical readings is defined as $P<0.05(*)$.

\section{Results}

Tree-ring series

The forest stands of the investigated plots differ considerably in their age structure. In the un-even aged stands mean tree age is 107 years, and the oldest tree is 291 years old, whereas in plantations the mean age is 54 years, with a maximum age of 69 years. The older trees were found mainly on north facing slopes. Although the distances between the plots are large (up to $50 \mathrm{~km}$ ), the mean "Gleichläufigkeit" (GLK) between the 26 mean ring-width series is remarkably high (average GLK $=71$ ) (Fig. 3). All the mean ring-width site chronologies for un-even aged walnut forests are characterized by a positive lagone autocorrelation (between $r=0.13$ and $r=0.35$ ). For plantations the lag-one autocorrelation is neglectable or even negative.

The Principal Component Analyses reduces the growth chronologies from 1960 to 2005 to eight main components with Eigenvalues $>1$. But only three components show values $>0.5$ in the component matrix and five components fulfil the criteria after the Varimax rotation (see Table 1). Without rotating the data the first three components can explain $75 \%$ of the variance. Component 1 is loaded by all growth chronologies of trees of un-even aged forests and Component 2 and 3 are loaded by chronologies produced from trees of walnut plantations. The mean annual growth (1960-2005) of the plantations is $2.5 \mathrm{~mm} /$ year, which is much higher than of those of un-even aged forests $(1.7 \mathrm{~mm} /$ year). This growth difference is however reduced after 1990 (Fig. 4).

The Varimax Rotation Components 1-5 explain $76 \%$ of the variance. Figure 5 shows that the five components are characterized by a different growth level, especially in the time period until 1990. After this year, the curves become more alike and variance is reduced. All the plots loaded by one rotated component belong to the same study area (either Arslanbob or Kara Alma) and to a similar altitude, whereas the principal component analysis does not separate plots from north- and south-facing slopes or of different inclinations. Component 1 is loaded by plots of the study area Kara Alma, mostly at higher altitudes $(1,700$ 2,000 m a.s.1.), with different aspect, slope inclination, origin and human impact. The plots show the highest mean growth $(2.1 \mathrm{~mm} /$ year $)$ among the sites in un-even aged forests. Component 2 is loaded by plots of the study area Arslanbob at higher altitudes with different aspect, slope inclination, origin and human impact $(1.5 \mathrm{~mm} /$ year). The plots of lowest growth $(1.3 \mathrm{~mm} /$ year $)$ in Arslanbob load Component 3. The sites are characterised by a strong human impact and are located at a lower altitude. North facing plots in un-even aged forests at lower elevations of Arslanbob (1.9 mm/year) load Component 4 and the plantations in flat terrain at lower elevation of Arslanbob, which show the highest mean annual increment of the sampled trees $(2.7 \mathrm{~mm} / \mathrm{year}$ ) load Component 5 (see Table 1). 

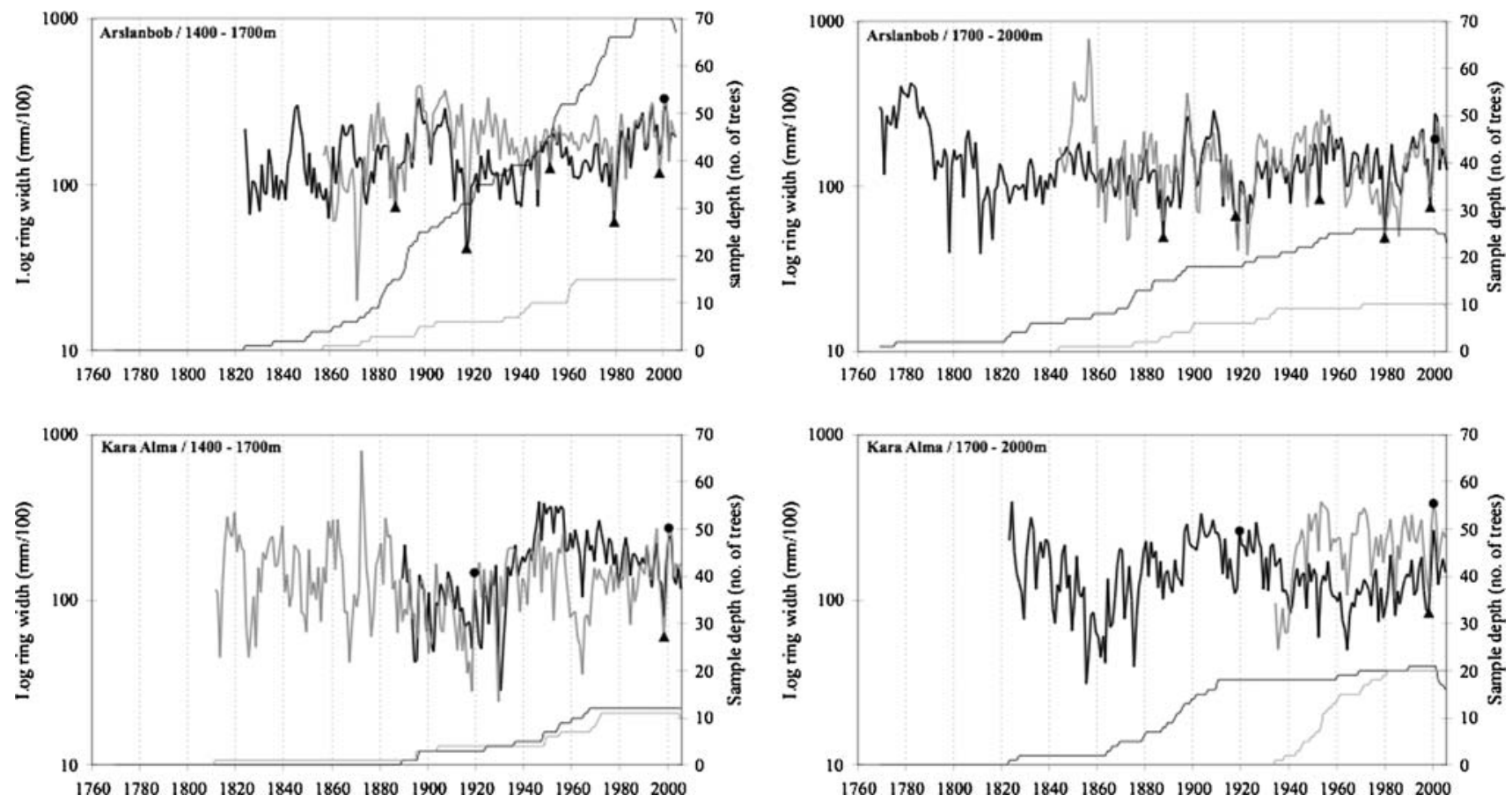

Fig. 3 Tree-ring chronologies of un-even aged forests on the north (black lines) and south facing slopes (grey lines) in Arslanbob and Kara Alma (closed circle positive pointer years, closed triangle negative pointer years)

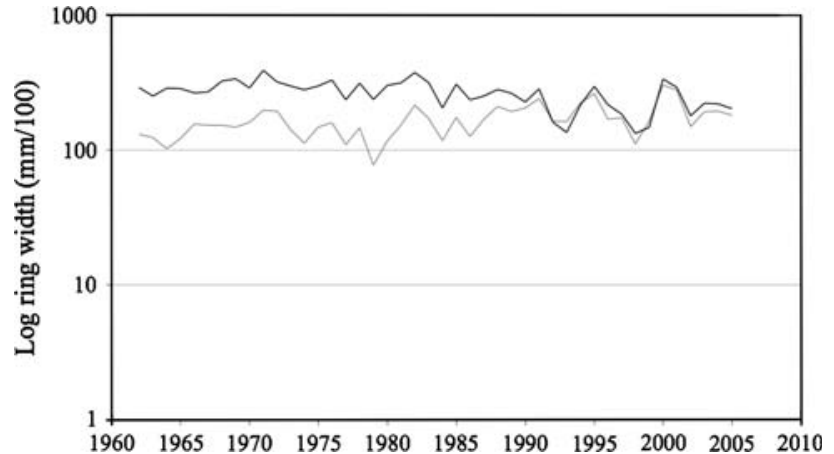

Fig. 4 Mean annual growth arranged in groups of different component loadings (Principal component analysis without rotation). Component 1 corresponds to growth of Juglans regia in un-even aged stands (grey line); Component $2+3$ correspond to growth of Juglans regia in plantations (black line)

Climate-growth relationships

In the region Kara Alma two positive regional pointer years could be found $(1919,2000)$. The year 2000 is classified as positive inter-regional pointer year, having been found also by Friedrichs et al. (2006) in their dendrochronological study of $J$. regia in Kyrgyzstan. Five negative regional pointer years occur in the Arslanbob region $(1887,1917$, $1952,1979,1998)$, whereas only the negative pointer year 1998 could be found in the Kara Alma region. Thus 1998 is an inter-regional negative pointer year (Table 2). Tree-ring analyses of Juniperus sp. in Kyrgyzstan and Pakistan made by Esper et al. (2001) also determined 1917 to be a year of remarkably poor growth.

Tree-ring width of un-even aged stands was significantly positively correlated with precipitation during the previous summer (July and August) and previous winter (November and December). In contrast, tree growth showed a negative correlation to precipitation during the current spring (April/ May). Annual growth was, partly significantly, negatively correlated with September and October temperatures of the previous year but showed a significant positive relationship to the temperature in May of the current year (Fig. 6). Although showing similar results, walnut trees of plantations showed generally less correlations to climatic data than those of the un-even aged stands. On plantations only a significant negative relationship between tree-ring growth and precipitation in May was found. By using the Preconsoftware approximately $50 \%$ of the growth could be explained by climatic events and $25 \%$ by prior growth. On the south facing slopes a lower percentage of growth could be explained by climatic influence. Late frost events have no significant effect on tree growth, regardless of aspect.

\section{Nut-crop series}

During the recorded period an increase in the amount of nut crop was recorded. The mean annual nut crop of the first recorded 20 years (1932-1951) was 490 tons, while the 
Fig. 5 Mean annual growth arranged in groups of different component loadings. (Principal component analysis with Varimax rotation)

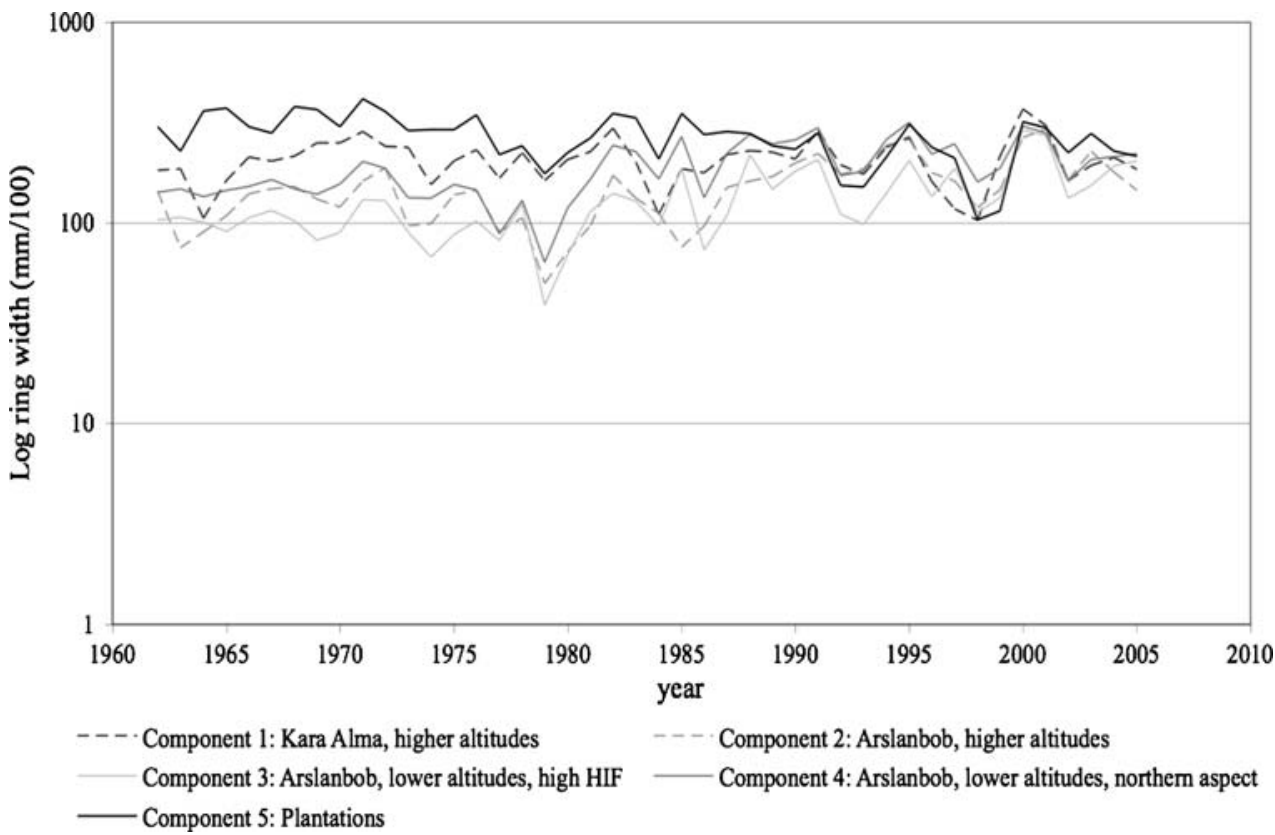

Table 2 Pointer years within tree ring chronologies of Juglans regia of Southern Kyrgyzstan and corresponding climatic events (mean monthly values $1947-2000$ in parenthesis)

\begin{tabular}{|c|c|c|}
\hline Pointer year & & Extraordinary climate conditions \\
\hline 1887 & Regional negative pointer year in Arslanbob & No data available \\
\hline 1917 & Regional negative pointer year in Arslanbob & No data available \\
\hline 1919 & Regional positive pointer year in Kara Alma & No data available \\
\hline 1952 & Regional negative pointer year in Arslanbob & $\begin{array}{l}\text { (High temperature in September } 21.0^{\circ} \mathrm{C}\left(20.1^{\circ} \mathrm{C}\right) \text { in } 1951 \\
\left.\text { and August } 25.8^{\circ} \mathrm{C}\left(24.6^{\circ} \mathrm{C}\right) \text { in } 1952\right)\end{array}$ \\
\hline 1979 & Regional negative pointer year in Arslanbob & $\begin{array}{l}\text { Little precipitation in February } 37,6 \mathrm{~mm}(56.5 \mathrm{~mm}) \\
\text { and March } 31.4 \mathrm{~mm}(79.8 \mathrm{~mm}) \\
\text { Coldest May of data record } 16.3^{\circ} \mathrm{C}\left(19.1^{\circ} \mathrm{C}\right)\end{array}$ \\
\hline 1998 & $\begin{array}{l}\text { Interregional negative pointer year } \\
\text { in Arslanbob \& Kara Alma }\end{array}$ & $\begin{array}{l}\text { Low temperature in May } 16.8^{\circ} \mathrm{C}\left(19.1^{\circ} \mathrm{C}\right) \\
\text { and June } 21.2^{\circ} \mathrm{C}\left(23.7^{\circ} \mathrm{C}\right) \\
\text { High temperature in September } 21.5^{\circ} \mathrm{C}\left(20.1^{\circ} \mathrm{C}\right) \\
\quad \text { and October } 17.1^{\circ} \mathrm{C}\left(13.0^{\circ} \mathrm{C}\right) \text { in } 1997\end{array}$ \\
\hline 2000 & Regional positive pointer year in Kara Alma & $\begin{array}{l}\text { Very high temperature during vegetation period } \\
\text { (April-September) } 23.3^{\circ} \mathrm{C}\left(21.3^{\circ} \mathrm{C}\right)\end{array}$ \\
\hline
\end{tabular}

mean crop during the period 1983-2002 was 780 tons (Fig. 7). The nut crop chronology is characterized by a significant negative lag-one autocorrelation $(r=-0.3)$.

\section{Climate-nut crop relationships}

The nut-crop series showed a partly significant negative correlation with precipitation of May and September of the previous year, and of January and August of the current year, and a positive correlation to precipitation in spring (February-April). Nut crop was significantly negatively correlated with temperature in October and November of the previous year. A significant positive correlation was found also with temperature in May and June of the previous year and with that of January of the current year (Fig. 8). Climatic effects explain 55\% and prior nut crop $13 \%$ of the variance in nut production. Comparing the nut crop with the occurrence of late frost (1983-2000), every late frost leads to a dramatic reduction in nut crop, but not every bad nut crop could be explained by late frost (see Fig. 7).

Tree growth-nut crop relationships

During the period from 1932 until 2002 a weak positive correlation between nut crop and tree growth of the same 
Fig. 6 Influencing climatic effects (temperature and precipitation) on radial growth of Juglans regia in un-even aged forests of Southern Kyrgyzstan illustrated in a response function graph

Fig. 7 Walnut chronology of the walnut-fruit forests in Southern Kyrgyzstan (1932-2002). Annual nut crop (solid line) and trend (dotted line) in comparison to late frost (circle)
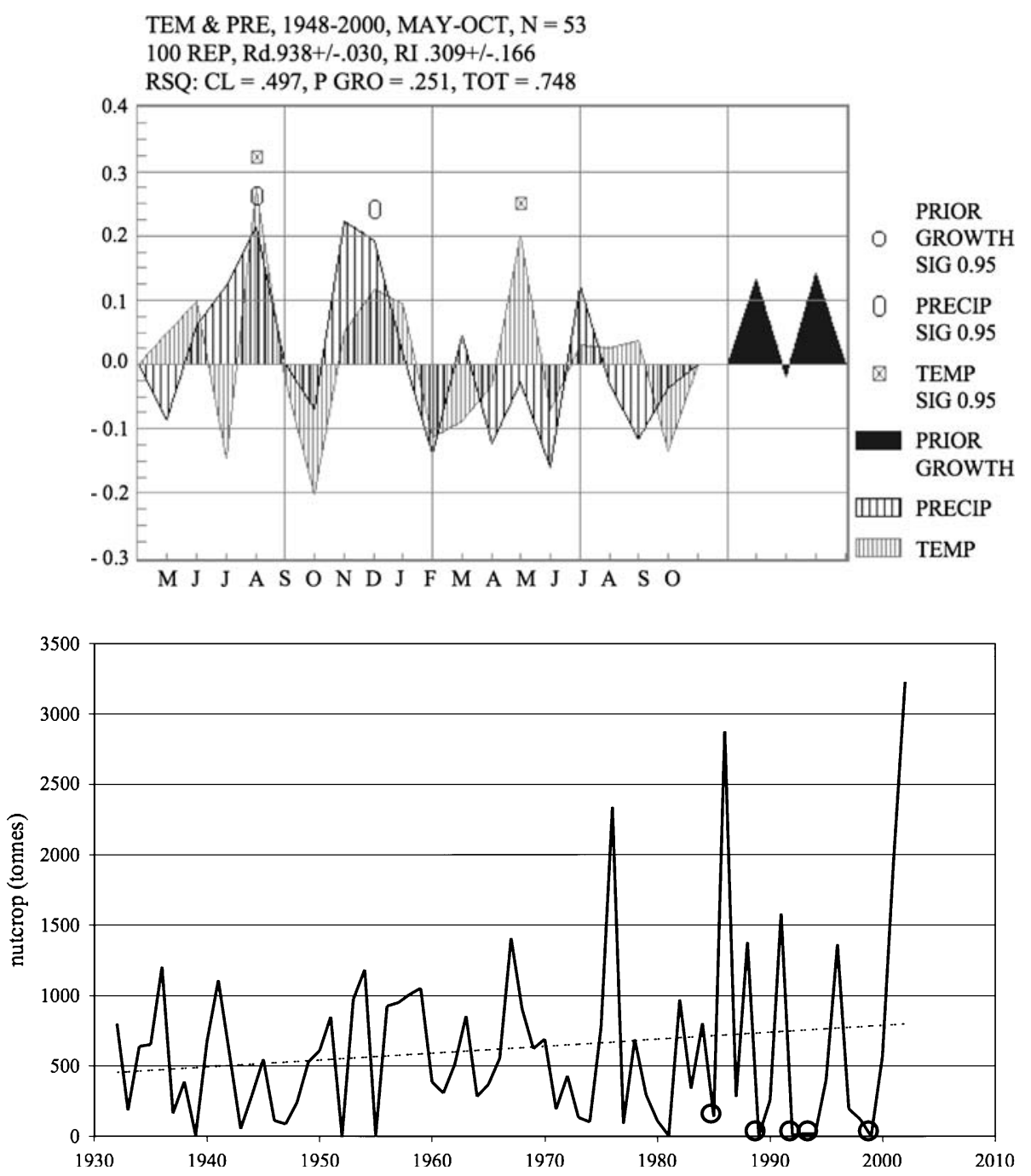

year $(x)$ was found $(r=0.163)$. The growth of the following year $(x+1)$ shows only a negligible negative correlation with nut crop of the current year $(x)(r=-0.054)$ as well as of the following years $(x+2 ; x+3)$. We found a significant correlation $(r=0.322)$ between tree growth of the previous year $(x-1)$ and nut crop of the current year. Tree growth and nut crop, when excluding climatic influences, show no significant correlations other than similar trend patterns.

\section{Discussion}

Tree-ring series

The tree-ring series show a high mean "Gleichläufigkeit". This indicates the presence of a common signal, possibly climatic, in all the tree-ring series, i.e. that tree growth is strongly influenced by external factors. This verifies our first hypothesis and justifies the use of tree rings of J. regia in this region for dendrochronological purposes.
In most cases the trees sampled on the north facing slopes were remarkably older than those on the south facing slopes. This might be strongly influenced by the intensity of human activities that differs due to topographical differences of the studied slopes. The forest stands sampled on south-facing slopes are mostly situated at flat sites and thus are more intensively influenced by human activity than those on north-facing slopes. This observation can be confirmed by the strong negative correlation $(r=-0.8)$ between slope inclination and HIF.

The strongest influences on tree growth, apart from the large-scale climatic conditions, seem to be micro site conditions. Interpreting the data of the PCA, neither the aspect nor the slope inclination seem to have a more important effect than the different conditions within the regions Arslanbob and Kara Alma or their sub regions. The various micro reliefs, the micro climate and different soil characteristics create conditions that promote or inhibit growth. Higher altitudes show more favourable conditions for tree growth in comparison to lower altitudes. At the end of the 
Fig. 8 Influencing climatic effects (temperature and precipitation) on nut production of Juglans regia of Southern Kyrgyzstan illustrated in a response function graph a TEMPERATURE, 1960-2000, JAN - DEC, $\mathrm{N}=41$

100 REP, Rd.876+/-.053, RI .289+/-.202

RSQ: $\mathrm{CL}=.501, \mathrm{P}$ GRO $=.091, \mathrm{TOT}=.592$

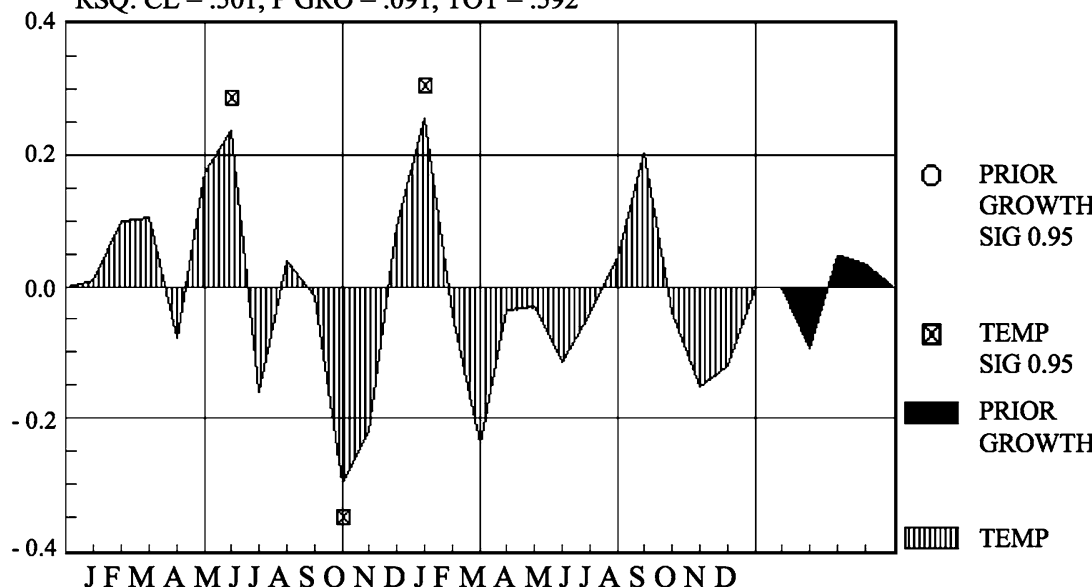

b PRECIPITATION, 1960-2000, JAN - DEC, N = 41

100 REP, Rd.927+/-.040, RI .306+/-. 187

$\mathrm{RSQ}: \mathrm{CL}=.550, \mathrm{P}$ GRO $=.165$, TOT $=.716$

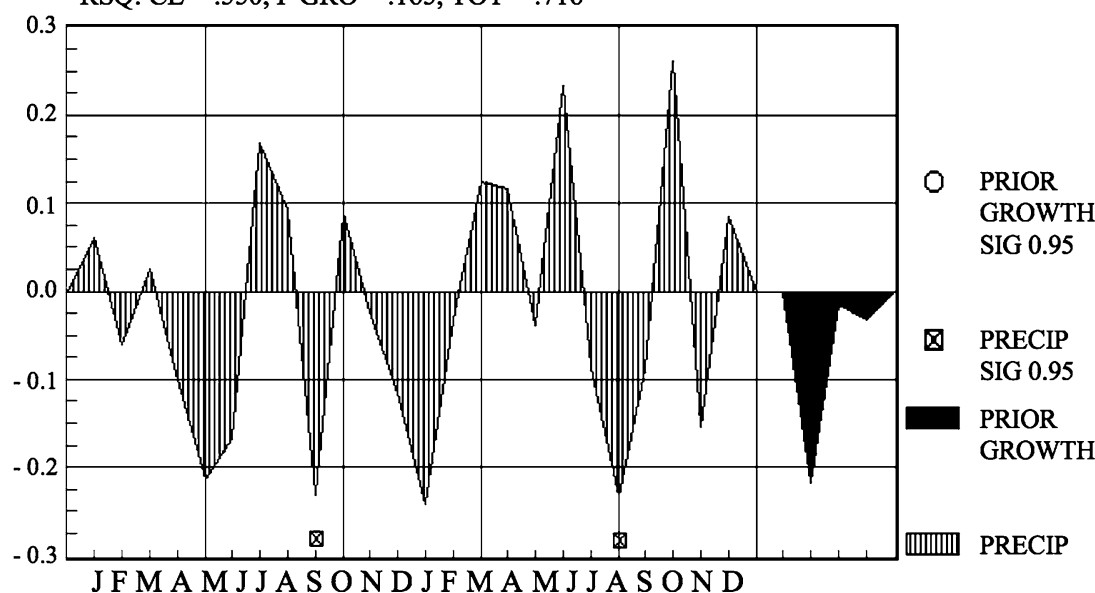

1980s all the growth curves classified by the PCA with rotation become more alike and the variance is reduced (see Fig. 5). The special growth conditions affecting tree growth in the single plots seem to be suppressed by an external factor influencing all trees in a similar way. A possible explanation might be changing climate conditions. A proof of this assumption would however go beyond the scope of this study and needs further investigations.

The positive lag-one autocorrelation, which explains $30 \%$ of the growth in un-even aged forests, is a phenomenon commonly observed in tree-growth studies. Tree growth in the current year is influenced by the growth conditions of the previous years, mainly through the amount of starch which could be stored in the stem (Woodward et al. 1994).

During the fieldwork in the walnut-fruit forests in 2005 a large number of egg depositions and dead imagines of gypsy moth (Lymantria dispar L.) were found on the stems. Since the early 1980s the annual gypsy moth outbreak area has ranged from 10,000 to 52,000 ha in Kyrgyzstan leading to defoliation and a significant decrease in walnut nut harvest and large economic losses (Orozumbekov et al. 2003). Because information was not available on the outbreak history record of gypsy moth, no statement can be made of possible effects on radial growth. A decrease in growth in years of defoliation is however probable, considering studies of the impact of L. dispar on other deciduous tree species in different regions (Naidoo and Lechowicz 2001).

As assumed in the hypotheses, overall tree-ring growth was remarkably higher in plantations than in un-even aged stands. Well organized thinning might minimize the negative effect of competition for nutrients, water and light. Moreover, plantations are situated in mostly flat areas, while the un-even aged forests are growing on slopes with a grade of up to $40^{\circ}$. The differences in growth patterns become obvious in the results of the principal component analysis, where the plantations loaded significantly other components than the plots situated in the un-even aged 

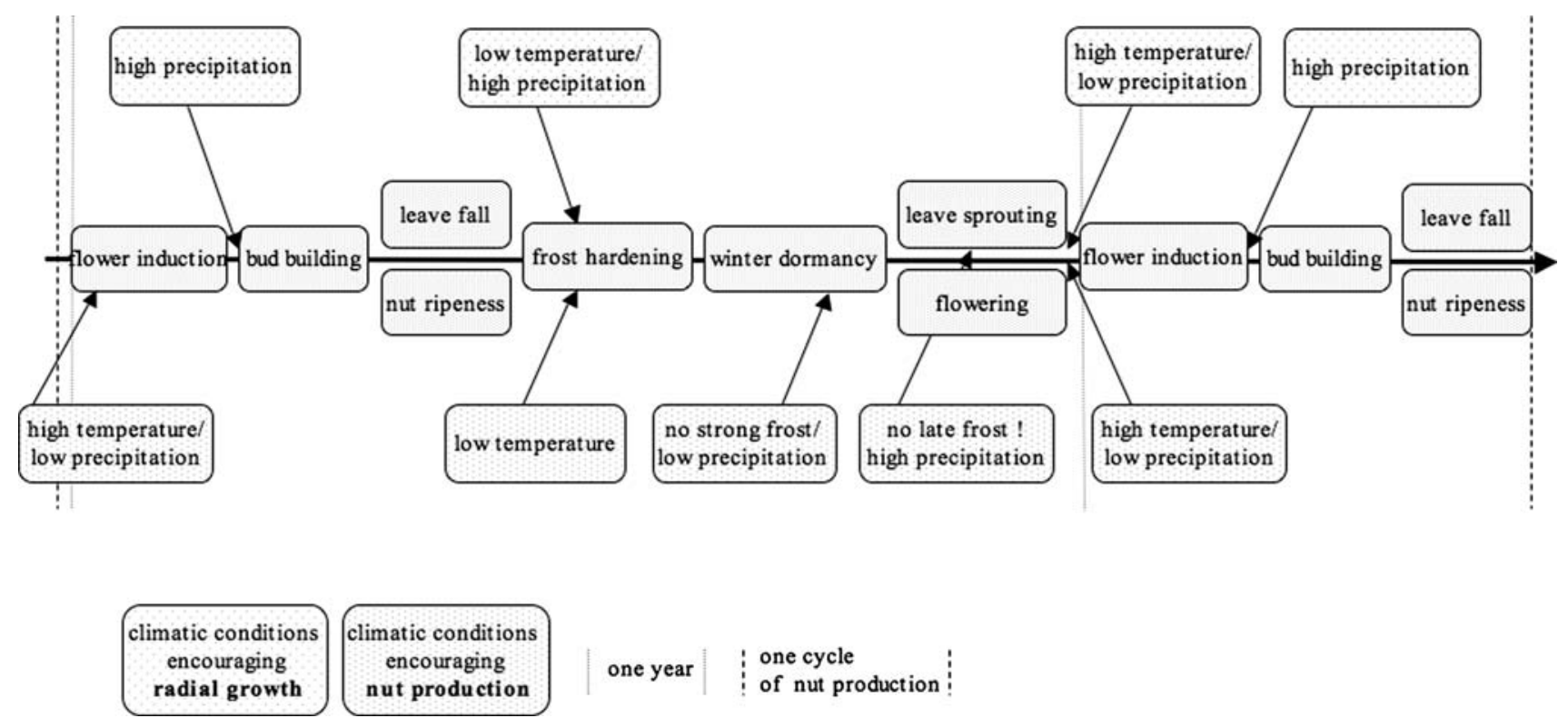

Fig. 9 Speculative influence of climatic conditions on physiological processes of tree-ring growth and nut production of Juglans regia

forests. These results show the potential of increasing growth rates through well organized thinning in the walnutfruit forests. Currently, the increasing demand for wood and the uncontrolled fellings lead to a decrease in biodiversity, a decline in forest cover and an overall degradation of these forests. The consequences are a decline in the protective functions of the forest and a reduced productivity (Schmidt 2005). A proper forest management scheme is needed and would increase wood production.

\section{Climate-tree growth relationships}

Most of the pointer years could be explained by extraordinary climatic events in the preceding or current year (see Table 2). Juglans regia is a thermophyllous species (e.g., Friedrich and Schuricht 1998). The positive inter-regional pointer year 2000 is a result of above-average warm temperature during the period of vegetative growth, especially in May. The tree ring formed in 1979, a regional negative pointer year in Arslanbob, was by contrast induced by exceptionally cool temperatures in spring and early summer. J. regia is demanding of special climatic conditions to promote optimal conditions for growth and nut production (Fig. 9). The significantly negative correlation between temperature in autumn of the previous year and tree growth and nut production may be due to the frost hardening process and the preparation for winter dormancy. In years with earlier frost (low temperatures after leaf fall in autumn), a higher level of resources stored as starch in the wood should be expected. These reserves could then be used for growth and reproduction in the next growing season (Selas et al. 2002). If there is no risk for a following late frost, J. regia profits from warm temperature as assumed in the hypotheses. A warm spring and early summer enables full-rate photosynthesis activity, leading to improved growth rates and nut development because of increased carbohydrate storage (Mathews 1963). Lack of precipitation in summer seems to be the limiting factor for tree growth. Frequently, there is no rainfall during the summer months (Gottschling et al. 2005). Water stress leads to lower tree vitality and growth in the following year. Important after such a dry period is the replenishment of the soil water storage in autumn and winter (November, December). Untypical for Central Asian conditions is a negative correlation between tree growth and precipitation as occurs in the walnut forests in spring. The plantations in flat terrain and on loamy soil in particular seem to have problems with very wet soils and probably reduced oxygen supply. J. regia is dependant on good soil aeration (e.g., Friedrich and Schuricht 1998). At the same time, permanent cattle grazing during the wet spring season leads to destruction of fine roots in the upper ground and therefore a less efficient transport of nutrients and water during the following summer (Gottschling et al. 2005). The negative correlation between tree growth and precipitation in early spring is, however, influenced by the high correlation between high temperature and low precipitation, which is common for May and June. The mean amount of precipitation in May of the 12 years with coldest temperatures (1947-2000) is $90 \mathrm{~mm}$, while the 12 years with the highest temperatures in May show a mean precipitation value of only $30 \mathrm{~mm}$. 
Nut-crop series

All the forests in Kyrgyzstan are property of the state and managed within lezhoses (forest services). The increasing trend in the amount of nut crop during the period 19322002 is certainly the result of past afforestation efforts. Between 1948 and 1966, 30,000 ha of walnut plantations were established in the forest (Blaser et al. 1998), enhancing the annual nut crop. In Southern Kyrgyzstan nut-crop series of walnut were characterized by a negative lag-one autocorrelation. The extent of current nut crop seems to influence the size of bud initiation and therefore the amount of next year's nut crop. As in other tree species, years of large seed production in J. regia are hardly found in two successive years (see Fig. 7). Within a 4-year time period, two nut crops tend to be on average, one above and one below average (Schaarschmidt 1999).

\section{Climate-nut crop relationships}

A high amount of rain in early summer, both in the flower induction and in the flowering year, appeared to have a negative effect on nut production (see Fig. 8). Probably a small drought during early summer in the year prior to nut crop stimulates floral induction, while dry weather in the nut production year favours pollen dispersion by wind and then positively influences the fertilisation of female flowers (Selas et al. 2002). Late frost can destroy flowers and young shoots of walnut trees. New shoots are rebuilt immediately but without a possibility of fruit breeding, which leads to a total absence of nut production in this year (Friedrich and Schuricht 1998).

Tree growth-nut crop relationships

The reproduction physiology of $J$. regia follows an endogenous cycle called alternate bearing (Crawley and Long 1995; Kozlowski and Pallardy 1997). Without external disturbances, such as late frost events or infestation by L. dispar, trees will build flower buds and nuts every year. Aside from the only weak positive correlation between nut crop and growth in the same year, no competition is apparent between the two physiological processes. Also, our results studying J. regia of Kyrgyzstan do not support the assumption of Powell (1977), that vegetative and reproductive growth share the same resources and that one occurs at the expense of the other. By this finding, our fourth hypothesis was disproved. The impact of nut crop on the following year's growth is negligible. Climatic conditions that positively affect radial growth stimulate the initiation of flower buds or further development of nuts (see Fig. 9). Juglans regia of Southern Kyrgyzstan shows no significant influence of nut production on radial growth, when excluding climatic factors. Analysing the relationships between cli- mate, tree growth and seed production for a period longer than 24 months, as limited by the Precon programme, would improve the quality of tree growth-nut crop investigations. Climatic influences, nut production and auto correlative effects cannot explain the whole variation in annual growth. Including the magnitude of disturbance through defoliation by Lymantria dispar in further studies may improve the validity for the investigated aspects.

\section{Conclusions}

The high mean "Gleichläufigkeit" of the tree ring series indicates the presence of a common signal, i.e. that tree growth is strongly influenced by external factors and justifies the use of tree rings of Juglans regia in this region for dendrochronological purposes.

The plantations in the walnut-fruit forests show, compared to the un-even aged forests, significantly higher growth rates revealing the potential of increasing growth through well organized thinning in the walnut-fruit forests. A proper forest management scheme could help to mitigate the negative impacts of the increasing wood demand that leads to a current decrease in biodiversity, a decline in forest cover and an overall degradation.

Excluding the climatic influence on the time series of radial growth and reproduction showed no significant correlation between the two parameters. These results might be strongly influenced by the large catchment area for the data sampling of the nut crops. Therefore, the influence of reproduction processes on radial growth of Juglans regia shall be considered in further studies with higher spatial differentiation (e.g. stand level) of nut crop.

Acknowledgments The authors wish to thank the Kyrgyz State forest service for data access and fieldwork permissions, the colleagues B. Tagaev (Municipality school Gumchana), I. Amatov (Technical University of Osh), D. Artykbaev (Biosphere Institute Jalal Abad), G. Lazkov (Komarov Institute St. Petersburg and Institute for Biology and Soil Science Bishkek), T. Narikev, K. Baltabaev, and J. Sauermann (FH Eberswalde) for help in the field work, U. Büntgen (WSL) for assistance in statistics and M. Dobbertin (WSL) for helpful discussions. Thanks to C. S. Eastaugh (University of Natural Resources and Applied Life Sciences, Vienna) and the two anonymous reviewers for helpful comments on a previous version of the draft. Financial support was provided by the Volkswagen Foundation under the research project of the Universities of Greifswald and Nürnberg/Erlangen (Germany) "The impact of the transformation process on human environmental interactions in Southern Kyrgyzstan” (2003-2006).

\section{References}

Academie Pédagogie Marseille (2009) Blank outline map Kyrgyzstan. Available online: http://histgeo.ac-aix-marseille.fr. Accessed on 18 March 2009 
Blaser J, Carter J, Gilmour D (eds) (1998) Biodiversity and sustainable use of Kyrgyzstan's walnut fruit forests. IUCN and INTERCOOPERATION, Bern

Bräker OU (1981) Der Alterstrend bei Jahrringdichten und Jahrringbreiten von Nadelhölzern und sein Ausgleich. Dickenwachstum der Bäume. Mitteilung der forstlichen Bundes-Versuchsanstalt Wien 142:75-105

Cook ER, Holmes RL (1986) User manual for program ARSTAN. In: Holmes RL, Adams RK, Fritts HC (eds) Tree-ring chronologies of Western North America: California, Eastern Oregon and Northern Great Basin. University of Arizona, Tucson, pp 50-65

Crawley MJ, Long CR (1995) Alternate bearing, predator satiation and seedling recruitment in Quercus robur L. J Ecol 83:683-696. doi: $10.2307 / 2261636$

Esper J, Treydte K, Gärtner H, Neuwirth B (2001) A tree ring reconstruction of climatic extreme years since 1427 AD for Western Central Asia. Paleobotanist 50:141-152

Friedrich G, Schuricht W (1998) Nüsse und Quitten. Neumann-Verlag, Leipzig

Friedrichs D, Neuwirth B, Gottschling H (2006) Dendroecological analysis of growth anomalies in walnut forests in Southern Kyrgyzstan. TRACE-Tree Rings in Archaelogy. Climatol Ecol 4:144-150 Fribourg

Fritts HC, Shaskin AV (1995) Modelling tree ring structure as related to temperature, precipitation and day length. In: Lewis TE (ed) Tree rings as indicators of ecosystem health. CRC Press, Boca Raton, $\mathrm{p} 1757$

Gan PA (1970) Lesa SSSR v pyati tomakh. Tom 5: Lesa Kazakhstana, sredneaziatskykh respublik i yugo vostoka evropeyskoy chasti SSR (in Russian) [The forests of the SSSR in five volumes, vol 5: The forests of Kazhachstan, the Middle Asian Republics and the south-east European parts of the SSSR], Moscow

Gan PA (ed) (1992) Orekhovo-plodovye lesa Yuga Kyrgyzstana (in Russian). [The walnut-fruit forests of Southern Kyrgyzstan]. Chast 1: (Fiziko-geograficheski usloviya) [physogeographical conditions]. Ilim, Bishkek

Gottschling H, Amatov I, Lazkov G (2005) Zur Ökologie und Flora der Walnuß-Wildobst-Wälder in Süd Kirgistan. Arch Naturschutz Landschaftsforschung 44:85-132

Gruber F (2003) Steuerung und Vorhersage der Fruchtbildung bei der Rotbuche (Fagus sylvatica L.) durch die Witterung. Schriften aus der Forstlichen Fakultät der Universität Göttingen und der Niedersächsischen Forstlichen Versuchsanstalt v. 136. Sauerländer Verlag, Göttingen

Guiot J (1991) The bootstrapped response function. Tree Ring Bull 51:39-41

Hemery GE, Popov SI (1998) The walnut (Juglans regia L.) forests of Kyrgyzstan and their importance as a genetic resource. Commonw For Rev 77:272-276

Kolov O (ed) (1997) Orekovo-plodovye lesa yuga Kyryzstana (in Russian) [walnut-fruit forests of South Kyrgyzstan], Chast 2. Bishkek, pp 62-95

Kozlowski TT, Pallardy SG (1997) Physiology of woody plants. Academic Press, San Diego

Mathews JD (1963) Factors affecting the production of seed by forest trees. For Abstr 24:i-xiii

Maydell HJv (1983) Forst- und Holzwirtschaft der Sowjetunion. Part 4: Kasachstan und die mittelasiatischen Sowjetrepubliken.
Mitteilungen der Bundesforschungsanstalt für Forst- und Holzwirtschaft, Hamburg

Naidoo R, Lechowicz MJ (2001) Effects of gypsy moth on radial growth of deciduous trees. For Sci 47(3):338-348

Orozumbekov AA, Ponomarev VI, Mamytov A, Andreeva EM, Liebhold MA (2003) Population ecology of gypsy moth in Kyrgyzstan. XIV USDA Interagency research forum on the gypsy moth and other invasive species. Annapolis, Maryland, pp 49-50

Owens JN (1995) Constraints to seed production: temperature and tropical trees. Tree Physiol 15(7/8):477-490

Pilcher JR (1990) Sample preparation, cross-dating and measurement. In: Cook ER, Kairiukstis LA (eds) Methods of dendrochronology. Kluwer, Dordrecht

Ponomarenko PN, Kenzhekaraev JB (1992) Climate. In: Kolov OV (ed) Orekhovo-plodovye lesa yuga Kyrgyzstana (in Russian) [The Walnut-Fruit-Forests in Southern Kyrgyzstan] Part 2, pp 52-95

Powell GR (1977) Biennial strobilus production in balsam fir: a review of morphogenesis and a discussion of its apparent physiological basis. Can J For Res 7:547-555. doi:10.1139/x77-072

Rinn F (1996) TSAP-Reference manual. Frank Rinn, Heidelberg

Schaarschmidt H (1999) Die Walnussgewächse. 2. Aufl. Die neue Brehm-Bücherei, Bd. 591, Hohenwarsleben

Scheuber M, Müller U, Köhl M (2000) Wald und Forstwirtschaft Kirgistans. Schweizer Z Forstwesen 151(3):69-74. doi:10.3188/ szf.2000.0069

Schmidt M (2005) Utilization and management changes in South Kyrgyzstan's mountain forests. J Mt Sci 2(2):91-104. doi:10.1007/ BF02918325

Schweingruber FH (1983) Der Jahrring. Standort, Methodik, Zeit und Klima in der Dendrochronologie. Haupt Verlag, Bern-Stuttgart

Schweingruber FH (1989) Jahrring- und Verkernungsmerkmale in Nussbäumen (Juglans regia L.) aus einer Aufforstung. Dendrochronologia 71:41-49

Schweingruber FH, Eckstein D, Serre-Bachet F, Bräker OU (1990) Identification, presentation and interpretation of event years and pointer years in dendrochronology. Dendrochronologia 8(9):9-38

Selas V, Piovesan G, Adams JA, Bernabei M (2002) Climatic factors controlling reproduction and growth of Norway spruce in southern Norway. Can J For Res 32(22):217-225. doi:10.1139/x01192

Sorg JP, Venglovsky BI, Schmidt K (2003) ORECH-LES: Biodiversity and sustainable management of Kyrgyzstan's walnut-fruit forests: development of new silvicultural approaches. Eur Trop For Res Netw News 38:65-67

Sukacev VN (ed) (1949) Plodovye lesa Yuzhnoy Kirgizii I ikh ispolzovanie. (in Russian) [The fruit forests of southern Kyrgyzstan and their utilisation]. AdW UdSSR, Moscow

Woodward A, Silsbee DG, Schreiner EG, Means JE (1994) Influence of climate on radial growth and cone production in sub alpine fir (Abies lasiocarpa) and mountain hemlock (Tsuga mertensiana). Can J For Res 24(6):1133-1143. doi:10.1139/x94-150

Zamoshnikov VD, Vienglovsky BI (2003) Nastavleniya po rubkam v lesakh Kyrgyzskoy Respublici (in Russian). [Instruction for the felling in the forests of the Kyrgyz Republic]. Gosudarstvennaya lesnaya sluzhba Kyrgyzskoy Respublici. Bishkek 